\title{
e-Government Systems Success and User Acceptance in Developing Countries: The Role of Perceived Support Quality
}

\begin{abstract}
The concept of e-Government was first developed and implemented in industrialised countries. Consequently, it should not be assumed that this concept is automatically appropriate for developing countries. This study aims to examine the roles of perceived support quality and support satisfaction in the context of government-to-citizen (G2C) transactions towards behavioural intention and usage in developing countries. To test the proposed model, the official website of Kuwait Government Online Services (KGOS) was selected. A survey with a total of 628 responses was analysed using Structural Equation Modelling (SEM) to investigate the goodness of fit of the model and the underlying indicators. The findings confirm the significance of support quality perceived by citizens and provide insights to explain citizens' intention to use e-Government systems.
\end{abstract}

Key words: e-Government, Developing Countries, SEM, Perceived Support Quality, Support Satisfaction 


\section{Introduction}

Information communication technologies (ICTs) have transformed the way governments deliver services to its citizens (Jacob et al., 2017; Seo and Hasan, 2015; Rabaa'i, 2015; West, 2008; West, 2006; West, 2004). Public sectors around the globe have invested increasingly in ICTs to improve productivity and to cut costs without sacrificing service quality. An expanding array of government services is now available online for their citizens. e-Government projects can create numerous benefits and opportunities for both governments and citizens in the world: Governments have realised cost reductions and improved efficiency, while citizens access services faster and more conveniently. e-Government services have potential to reshape public sectors: the services revise relationships between citizens, businesses, and the government by enabling open communication, participation, transparency, and public dialogue in formulating national regulations (Bhattacharya, Gulla and Gupta, 2010; West, 2004; West, 2001).

ICTs have dramatically revolutionised the processes, operations, and structure of public sectors, which are almost universally adopted or on the verge of being adopted by both developed and developing countries. However, the primary problem of technology-enabled modernisation is that decision makers often do not consider user expectations and preferences. Rather, to some extent, they only focus on cost efficiency and e-government systems design (Rabaa'i, 2015; Verdegem and Verleye, 2009). Thus, a challenge facing e-Government services is not solely technological issues (Heinze and $\mathrm{Hu}, 2005$ ); indeed, the challenge is to use those technologies to improve the abilities of government's institutions while improving the quality of citizens' lives by redefining the relationship between them and their governments (Gautrin, 2004).

Lots of efforts are being invested in the use of ICTs to improve delivery of government services to citizens in developing countries (Basettihalli et al. 2010; Pudjianto et al. 2011; Weerakkody, Molnar and El-Haddadeh, 2014; Hien, 2014; AlAwadhi and Morris, 2009; Al-Shafi et al., 2009; Verdegem and Verleye, 2009; Galpaya, Samarajiva and Soysa, 2007). Accordingly, the improvement of eGovernment services has been one of the most popular research topics within this 
research area over the last decade (Barrett et al., 2015; Andersen, Henriksen and Medaglia, 2010; Kanat and Özkan, 2009; Carter and Weerakkody, 2008; West, 2008; Norris and Moon, 2005; Gilbert, Balestrini and Littleboy, 2004; Heeks, 2002; Layne and Lee, 2001; Venkatesh and Morris, 2000). One of the initiatives is to evaluate and improve e-Government services from the citizens' perspective (Cruza et al. 2016; Rabaa'i, 2015; Abu-Shanab, 2014; B. Gupta, Dasgupta and Gupta, 2008; D. N. Gupta, 2007). The adoption and use of e-Government services remain restricted in the most countries due to being guided largely by supply side factors (Verdegem and Verleye, 2009; Kolsaker and Kelley, 2007). Governments must realise that the success of e-Government does not depend only on the supplier side, but also on the demand side and the willingness of citizens to adopt the online service (Anthopoulos et al., 2016; Rabaa'i, 2015; Carter and Bélanger, 2005).

The dilemma of e-Government service adoption and usage is its complexity and multidimensionality (Al-Hujran, Al-dalahmeh and Aloudat, 2011). e-Government was developed and implemented firstly in industrialised countries; it should not be assumed that the concept of e-Government is innately appropriate for developing countries. Consequently, it should not be assumed that the concept is automatically appropriate for developing countries. Thus far, e-Government still faces major challenges as it continues to expand in developing countries. Moreover, when introducing e-Government to developing nations, it is anticipated that more efforts will be necessary than in developed countries.

The end-users of e-Government systems are more diverse than e-Commerce, with comparisons of wider layers of user groups (for example, elderly, less welleducated people and less familiar with technology usage) who are more likely to encounter problems while interacting with e-Government systems. IS literatures confirmed that users' technical capabilities and management support are influenced by user's technical knowledge and expertise. Therefore, this research argues that perceived support quality is a new way of looking at citizens' adoption and usage in the e-Government system's field and a major factor of e-Government system's acceptance, particularly in developing countries. 
The objective of various e-Government initiatives has moved in the past decade towards establishing services offering greater accessibility for citizens (Rabaa' $i$, 2015; Al-Hujran et al., 2015; Carter and Bélanger, 2005). As a result, it is necessary to examine all possible factors to explain citizens' adoption and usage of such systems. Until now, e-Government services have been more concerned with quantity rather than quality (Weerakkody, Molnar and El-Haddadeh, 2014; West, 2008; The Economist, 2008). While there have been numerous researches on eGovernment adoption in developing countries, little has been known about the role of perceived support quality on e-Government adoption. This is important because citizens require continuous guidance while interacting with the system.

However, the perceived support quality in an e-Government system has not been looked at closely yet. What is more, the concept e-Service has been studied less in the public sector (Wang and Liao, 2008; Buckley, 2003). Therefore, this research argues that perceived support quality is a new way of looking at citizens' adoption and usage in the e-Government system's field and the major factor of e-Government system's acceptance, mainly in developing countries. According to the model of Wixom and Todd (2005), the perceived support quality is a weaker predictor of systems usage than technology acceptance. But, we found that the perceived support quality is one of the major success factors of e-Government system in developing countries that increase the e-Government system usage.

Thus, the objective of this paper is to advance our knowledge in the field of eGovernment by revealing the roles of perceived support quality and its satisfaction towards behaviour intention and usage of e-Government services in developing countries. We review relevant studies and theories regarding e-Government adoption and information in Section 2 and the research model of the study is discussed in Section 3. The research methodology of the study is presented in Section 4, followed by the data analysis and results in Section 5. We conclude the study in section 6 with discussion and recommendation. 


\section{Conceptual Background}

There are several definitions in the existing literature that attempt to classify the concept of e-Government systems according to their scope, perspectives, and the objective of their activities (Hu et al., 2009). However, this study will focus on the definitions relating to citizens' perspectives towards e-Government services. As per the report on "Auditing e-Government" prepared by the INTOSAI Standing Committee on IT Audit (2003), the definition of e-Government is: "the online exchange of government information with, and the delivery of services to, citizens, businesses and other government agencies". Similarly, then United Nations and the American Society for Public Administration (ASPA) (2002) defined e-Government as, "utilizing the Internet and the World-Wide-Web for delivering government information and services to citizens". Furthermore, Deloitte Research (2000:1) defines e-Government as the "use of technology to enhance the access to and delivery of government services to benefit citizens, business partners and employees."

As noted in the above three definitions, the Internet is defined as a requirement and a possible medium for e-Government, which emphasises the importance of ICT in this environment. Additionally, all definitions of e-Government include the use of technology to enable information and service delivery by transforming internal and external relationships, and can be defined as a method "of delivering government information and services digitally to citizens and businesses" (Molla and Licker, 2001).

There is a number of empirical studies undertaken in different countries to study e-Government adoption; for example, in Turkey (Ozkan and Kanat, 2011), the USA (Carter and Bélanger, 2005), the Netherlands (Horst, Kuttschreuter and Gutteling, 2007), the UK (Dwivedi and Williams, 2008), Kuwait (AlAwadhi and Morris, 2009), Qatar (Al-Shafi and Weerakkody, 2009), Saudi Arabia (Al-Sobhi, Weerakkody and Al-Shafi, 2010) and Jordan (Rabaa'i, 2015; Abu-Shanab, 2014).

Each study contributes to providing a strong theoretical understanding of the factors explored in their research model. Nations are motivated globally to make improvements in their governments, build stronger relationship with citizens, 
improve efficiency and effectiveness of government agencies and reduce costs of service delivery in the form of e-Governments (Shahkooh, Abbasi and Abdollahi, 2008). Therefore, the expectations from implementing e-Government systems in developing countries are high and regarded as a prerequisite for economic and social development (Weerakkody, Dwivedi and Kurunananda, 2009; Schuppan, 2009). Some of the social challenging to use e-Government services as outlined by Weerakkody, Dwivedi and Kurunananda (2009) are accessibility of eGovernment services and language barriers.

During the last decade, numerous reports and articles were published in the field of e-Government emphasising the beneficial services offered in developed countries (Hien, 2014; Song, 2010; Sharifi and Zarei, 2004); for example, health, education, immigration, traffic, and many other services provided electronically. Many international agencies and developed countries including the UN, World Bank, OECD, US, the UK make reports as a form of institutional and academic publications. Those reports and articles discuss the progress of nations in terms of delivering e-Government systems by highlighting: (1) the critical factors that influence the success or failures of such systems; (2) evaluating the results from the implementation of e-Government; and (3) adding recommendations for future improvements (e.g., Chatfield and Alhujran, 2009).

\section{Theoretical Framework}

This research aims to reveal the role of perceived support quality and satisfaction towards intention of use of e-Government systems in Kuwait, as an example of cases of e-Government adoption in a developing country. The basis of the hypothetical model of this study is based on Wixom and Todd theoretical integrated model (2005). Using Ajzen and Fishbein's (1988) conceptualisation of attitudes; object-based versus behavioural beliefs, the authors integrated the two research streams recommending more predictive means of measuring systems usage and tested it in a database application environment and poses that there are two welldeveloped streams in the literature that seek to measure IS success: (1) usersatisfaction literature; and (2) technology acceptance literature. The model 
recognises that user-satisfaction is a weaker predictor of systems usage than technology acceptance. To fulfil the goals of this study, a modified model of Wixom and Todd integrated model was used, which made some changes to the original model of Wixom and Todd.

Firstly, the present study employs the UTAUT model as a replacement for the TAM model, which was used in the original Wixom and Todd theoretical model. The line of research in technology acceptance literature is crowned by UTAUT. The empirical test of the original UTAUT provides strong support for the model and was developed as "a definitive model that synthesizes what is known and provides a foundation to guide future research in this area" (Venkatesh et al., 2003 :467). Thus, the model serves as a benchmark for the technology acceptance literature and aims to explain user intentions to use IS and subsequent usage behaviour (AlAwadhi and Morris, 2009; Venkatesh et al., 2003). Nonetheless, despite the credited work of integrating various models in UTAUT, the model lacks important variables, such as web quality, assurance of service by service providers and responsiveness of service providers (Sambasivan, Wemyss and Che Rose, 2010). Furthermore, compared with the TAM model, UTAUT has been less studied in the context of eGovernment. To reduce this gap, we develop a unified model for the study.

Secondly, the updated De Lone and McLean's IS success model (2003) is employed as a replacement for the 1992 De Lone and McLean IS success model (D\&M IS success model), to include the service quality construct in framework. Livari (2005:8) outlined that, regardless of the popularity of the D\&M IS success model, it was tested empirically on 16 studies only: "there is a dearth of studies that tested DeLone-McLean model empirically." In this aspect, IS literature has been silent about what really contributes to the success of e-Government websites (Teo, Srivastava and Jiang, 2008; Carter and Bélanger, 2005). Despite the considerable interest in the D\&M IS success model, few efforts were made concerning the third critical success factor, 'service quality', in the context of e-Government (Saha, Nath and Salehi-Sangari, 2010; Song, 2010; Wang and Liao, 2008). 
Figure 3-1 Illustrates the Proposed Framework of this Study.

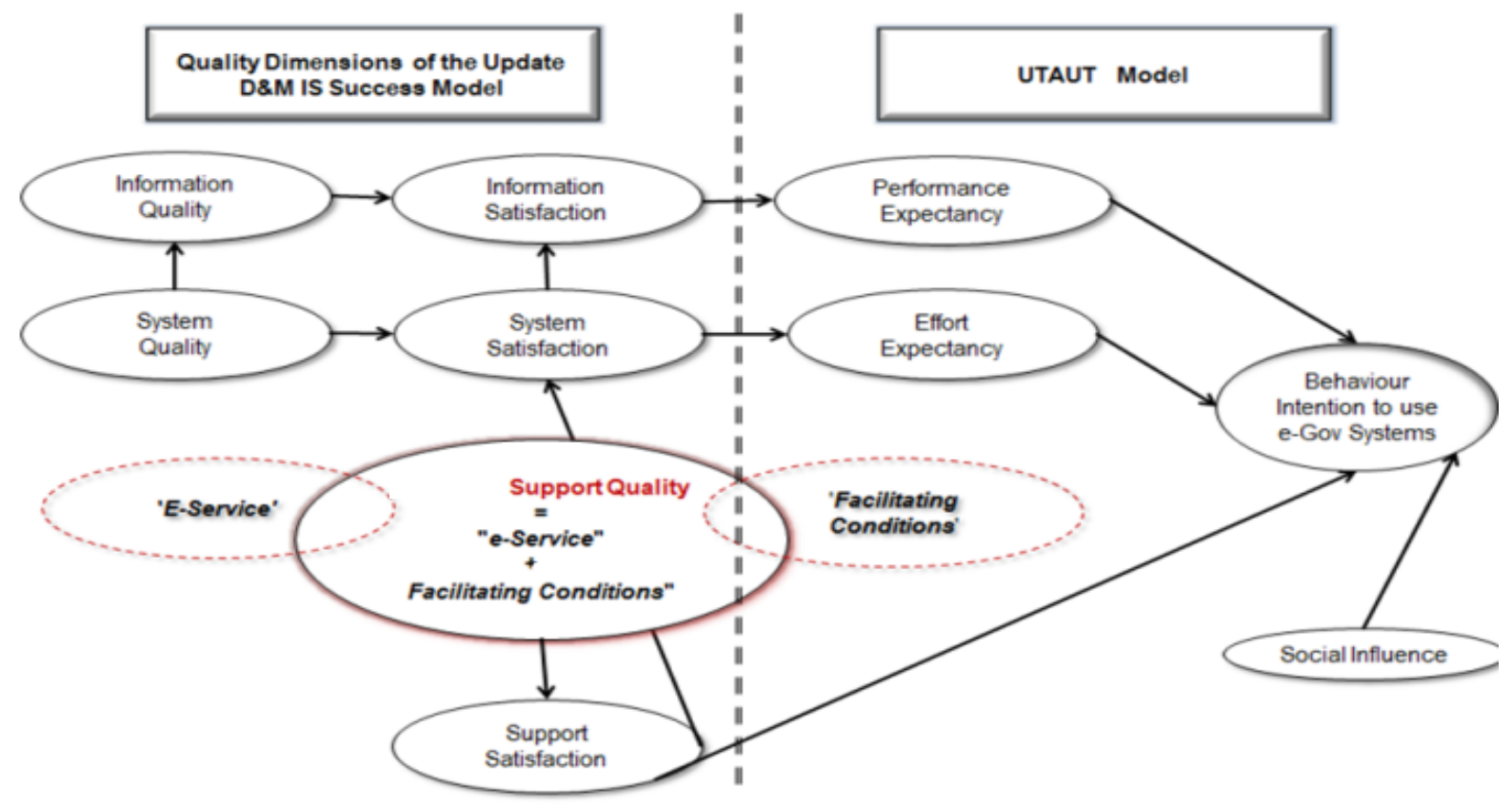

In line with the empirical study of Wixom and Todd, this research integrates the quality dimensions from the IS success literature with the technology acceptance literature to symbolise a more relevant model for e-Government systems. This will be achieved by revealing the roles of perceived support quality and satisfaction. The proposed research model illustrates relationships among the constructs of the quality dimensions and the constructs of the UTAUT model to have a better understanding of citizens' acceptance and adoption of e-Government systems.

The proposed integrated research framework is comprised of ten constructs; one dependent variable and nine independent variables (see Figure 3-1). The dependent variable is behavioural intention to use e-Government systems while the independent variables are: (1) information quality, (2) information satisfaction, (3) system quality, (4) system satisfaction, (5) performance expectancy, (6) effort expectancy, (7) social influence, (8) perceived support quality and (9) support satisfaction. The constructs in the proposed integrated research framework have been used frequently in IS research (e.g., DeLone and McLean, 2004; DeLone and McLean, 2003; Venkatesh et al., 2003; DeLone and McLean, 2002; Molla and Licker, 2001; Seddon, 1997; Seddon and Kiew, 1996). However, other constructs 
than the perceived support quality and support satisfaction do not directly relate to our study, so we did not develop and test the hypotheses related to these constructs. For the integrity of the research model, the process of defining and verifying each construct proceeded. Accordingly, three hypotheses were formulated to test the research model.

\subsection{The Quality Constructs of the Updated D\&M IS Success Model}

DeLone and McLean (2003) posit that there are three scopes of quality in any system: system quality (technical level); information quality (semantic level); service quality (the support that users receive from the IT support personnel); all of which impact the dimensions of satisfaction (DeLone and McLean, 2016). Additionally, to receive the maximum benefit of e-government service, there should be a continued usage of e-Government services (Alalwan, 2013). In the eGovernment domain, citizens use an internet-based application to search and conduct transactions; therefore, they require e-Government systems to provide high-quality information and first-class service. Doing so will satisfy citizens' needs and encourage them to re-use e-Government systems.

\subsection{The UTAUT Constructs}

The original UTAUT model comprises three indirect determinants of behavioural intention and two direct determinants of use behaviour. The three core constructs of the original UTAUT model that declare to impact behavioural intention directly to use technology are: (1) performance expectancy, (2) effort expectancy and (3) social influence. Behavioural intention and facilitating conditions are declared to impact directly use behaviour. However, the moderators (age, gender, experience and voluntariness of use) were not included in this study since Wixom and Todd did not include any of the moderators in their study.

The dependent variable in this study is behavioural intention to use e-Government systems. The intention to use technology is a central factor in TAM and UTAUT models and can also be used to predict the citizens' actual technology usage. Due to the difficulties of interpreting the multidimensional aspects of use, DeLone and 
McLean (2003) suggest intention to use as an alternative measure in some contexts. The intention-behaviour relationship is well documented in the technology acceptance literature and has been found to be distinct when applied to a variety of technology contexts (Kim, Chun and Song, 2009; Venkatesh et al., 2003; Davis, Bagozzi and Warshaw, 1989). As a result, the link between intention to use a technology and actual usage is well established and either variable may be used to measure technology acceptance (DeLone and McLean, 2003; Taylor and Todd, 1995a; Mathieson, 1991).

\subsection{Perceived Support Quality}

\section{Perceived Support Quality and Support Satisfaction}

The current study attempts to examine role of perceived support quality and support satisfaction in the context of e-Government. The support delivered by the service providers, government's administration and the personal IT towards intention to use e-Government systems, could be a critical factor in explaining the behavioural intention towards, and usage of, e-Government systems. Most of the IS acceptance models in previous studies consider end-users to be homogeneous in terms of their technology skills. However, in developing countries, citizens are mostly novices in terms of using IT. On the one hand, IS users in the workplace are more skilled and ready to use such systems, due largely to the training they receive. Alternatively, the reverse is evident in e-Government systems. Their users, citizens, may include those who are less familiar with technology-enabled systems; for example, elderly, less well-educated people, the disabled and the less ICT savvy, who are more likely to encounter problems while interacting with e-Government systems. Such systems have wider layers of user groups compared with other IS. Phang et al. (2006) state that the provision of e-Government services to citizens should cover all sections of the public: rich, poor, young and elderly. Additionally, Galpaya, Samarajiva and Soysa (2007:2) declare: "Decreasing existing disparities in access, is, in fact, the holy grail of e-Government projects." In view of these prior studies, based on the integration of the two models, the construct 'service quality' from the updated D\&M IS success model and the construct 'facilitating conditions' from the UTAUT 
model are merged and renamed 'perceived support quality' in an attempt to explain the behaviour intention to use e-Government services.

\section{Service Quality and Facilitating Conditions}

Facilitating conditions is defined as the "degree to which an individual believes that an organizational and technical infrastructure exists to support the use of the system" (Venkatesh et al., 2003:453). The literature indicates that facilitating conditions has a positive effect on innovation use and is considered a significant predictor of technology use (Venkatesh et al., 2003; Chau, 2001; Taylor and Todd, 1995b) . Facilitating conditions reveal workplace environmental conditions that support employees' use of technology; that is, the availability of computers, and having the necessary resources, knowledge and opportunities to use the system. Notwithstanding, in the realm of e-Government, citizens require more than environmental conditions to support their use of online services.

Due to the advent and growth of e-Commerce, DeLone and McLean added the construct of service quality to their updated model and declared that it "may become the most important variable" in an IS context (DeLone and McLean, 2003:25). One of the most important distinguishing features of the terms 'service quality' and 'electronic services' is "the replacement of interpersonal interaction with human-machine interaction" (Bressolles and Nantel, 2008:3). Thus, due to the lack of personal communication between users and website managers, service quality measure has become a vital issue in the web environment and could be the most important variable in the update DeLone and McLean model (Tam and Oliveira, 2017; Ahn, Ryu and Han, 2004).

Accordingly, online services that meet users' needs and are able to solve their problems are described as electronic services or e-Services (Hoffman, 2003). Nevertheless, it is a subjective assessment of the service citizens expect to receive and is usually based on citizens' special assessment. As a result, when these two constructs are combined, the criteria may yield to a stronger overall measure of perceived support quality. In an e-Government setting, technical and managerial support to citizens is fundamental as they are likely to seek help while interacting with the system. Therefore, the greater the citizens' perception of the quality of support received online, the more likely they are to be satisfied and inclined to use the e- 
Government system again. The discussions above lead to the following hypothesis being formulated:

H1: Perceived support quality is related significantly to support satisfaction of an e-Government system.

\section{Support Satisfaction and Intention to Use}

The findings of a study conducted by Al-adaileh (2009) in the context of Arab countries revealed that the use of IS is influenced by users' technical capabilities and the management support provided. High-quality services and users' satisfaction are recognised as predictable dimensions that lead to continues use of e-service (Tam and Oliveira, 2017). To be precise, 'use' and 'user satisfaction' are closely interrelated (DeLone and McLean, (2003); therefore, when citizens are satisfied with the support of the e-Government system, they are more likely to use the system. Thus, the discussions above lead to the following hypothesis:

H2: Support satisfaction is related significantly to intention to use eGovernment system.

\section{Support Satisfaction and System Satisfaction}

According Molla and Licker (2001), the previous experience of high-quality online customer support might affect repeated use of the commercial site. That is, the system can be perceived as successful if the quality of online helpdesk support is high, thereby satisfying the users. Moreover, in discussing the concept of IS success in Germany, the perception of 'help-desk support quality' emerged from the analysis (Agourram, 2009: 134). Therefore, when citizens perceive high online support while interacting with e-Government systems, they will be satisfied. In turn, this will lead to ease-of-use of the system or 'effort expectancy'. Thus, the discussions above lead to the following hypothesis:

H3: Support satisfaction is related significantly to system satisfaction. 
Table 3-1List of the Thirteen Research's Hypotheses

\begin{tabular}{ll}
\hline No. & Summary of Research Hypotheses \\
\hline H1 & $\begin{array}{l}\text { Perceived support quality is related significantly to support satisfaction of e-Government } \\
\text { system. }\end{array}$ \\
\hline H2 & $\begin{array}{l}\text { Support satisfaction is related significantly to behavioural intention to use e-Government } \\
\text { system. }\end{array}$ \\
\hline H3 & Support satisfaction is related significantly to system satisfaction. \\
\hline
\end{tabular}

\section{Research Methodology and Methods}

\subsection{Research Methodology}

Technology adoption research is a well-established field within the literature. Therefore, to achieve the research aim and meet the objectives, the study focuses on measurement techniques to understand the behaviour intention to use $\mathrm{e}$ Government systems and their sustained use. Hence, a quantitative empirical approach was best suited to this approach, considering the 'what' and the 'how' research questions. Accordingly, the study is categorised under the scientific method following a hypothetico-deductive approach. From the perspective of the philosophy of science, the validation of the positivist research instruments is a necessity for discovering the truth (Nunnally and Bernstein, 1994). Therefore, in line with the positivist paradigm, a deductive research would be an applicable approach when considered against its philosophical background. As a result, this research sought a theoretical argument through the deduction of a sequence of hypotheses. These are identified as important variables according to Wixom and Todd's tested theory by applying those variables in the e-Government context and then, collecting appropriate data via questionnaire to be analysed empirically in the following chapter. The aim of the methodology is to ensure systematic and relevant research into the phenomena under investigation.

\subsection{Kuwait Government Online}

Effectiveness is the main aim organizations pursue to ensure that their investments in information systems (IS) are successful (DeLone and McLean, 2016). To answer the research questions, and to test the proposed model, the state of Kuwait's official website (KGOS, http://www.e.gov.kw/) was chosen as an application area. Kuwait is a small oil-rich country 
located in the Middle East. Due to its substantial oil resources, it is considered the second wealthiest country in the Gulf Cooperation Council (GCC). However, even in rich and booming countries, organizations seek effectiveness and success in their investments in information systems (DeLone and McLean, 2016).

On June 30, 2008, the population of Kuwait was estimated at 3,328,136 people. In this census, the number of Kuwaitis reached 1,038,598, while the remainder comprised non-Kuwaitis. The KGOS portal was launched in 2005, presenting governmental information and services to all citizens, residents, and visitors in addition to business sectors. KGOS provides many services online such as traffic offenses for individuals and transfer of residence; license declarations and tenders; and online services for visitors like information about the climate in Kuwait. Finally, KGOS provides e-Payment system to assist the electronic payment of governmental fees at any time in a fast and secure way. The total payments by e-Payment through KGOS amounted 7,721,956 KD (around USD 27 million) and the total number of visitors was 2,147,257 for the first half of 2013. By 2006, more than 50 government services were available through the e-Government official website. The launch of KGOS signified a basic change to the concept of presenting information and delivering government services. According to the Internet Usage Statistics, $74.2 \%$ of Kuwait population has Internet access (Internet World Stats, 2012). However, according to a survey was taken on March 7, 2010 by one of the leading newspapers in Kuwait, 56\% of people in Kuwait use the Internet for entertainment and recreation purposes. In addition, 38\% were unsatisfied with the Internet services in general (Alqabas Newspaper, 2011).

There are three main reasons for choosing Kuwait as the setting for this study. First, according to the World Bank Group (2004) classification, Kuwait was categorised by the United Nations as a developing country in 1995, despite its high per capita income. The developing countries includes Hong Kong (China), Israel, Kuwait, Singapore and the United Arab Emirates (UAE) (2004). It is the main reason to choose Kuwait in this study that Kuwait is one of the developing countries. Second, the lack of IT skills in implementing effective e-Government system in Kuwait makes Kuwait a good application area. Third, Kuwait is one of the members of the Gulf Cooperation Council (GCC) which consists of Oman, Bahrain, Kuwait, Qatar, Saudi Arabia and the UAE. The GCC countries have similar political systems based on Islamic beliefs, joint destiny, and common objectives. Nevertheless, Bahrain has emerged as the new 
leader in the region, while Kuwait has slipped to a lower position (United Nations, 2010). Also, the instability in performance on EPI for some countries such as Kuwait can be attributed to so many factors such as lack of openness, lack of awareness, lack of trust in both, government and the Internet (AlAthmay, 2013). For these reasons, Kuwait is one of the representative countries in the Gulf area that meets the research's requirements.

Table 4-1 e-Government Readiness Index (2010, 2012): Top 50 Countries

\begin{tabular}{|c|c|c|c|c|c|c|c|c|c|}
\hline \multirow[t]{2}{*}{ Country } & \multirow{2}{*}{$\begin{array}{c}\text { Index } \\
2010\end{array}$} & \multirow{2}{*}{$\begin{array}{c}\text { Index } \\
2012\end{array}$} & \multicolumn{2}{|c|}{ Global Ranking } & \multirow{2}{*}{ Country } & \multirow{2}{*}{$\begin{array}{c}\text { Index } \\
2010\end{array}$} & \multirow{2}{*}{$\begin{array}{c}\text { Index } \\
2012\end{array}$} & \multicolumn{2}{|c|}{ Global Ranking } \\
\hline & & & 2010 & 2012 & & & & 2010 & 2012 \\
\hline Republic of Korea & 0.8785 & 0.9283 & 1 & 1 & Israel & 0.6552 & 0.8100 & 26 & 16 \\
\hline USA & 0.8510 & 0.8687 & 2 & 5 & Hungary & 0.6315 & 0.7201 & 27 & 31 \\
\hline Canada & 0.8448 & 0.8430 & 3 & 11 & Lithuania & 0.6295 & 0.7333 & 28 & 29 \\
\hline UK & 0.8147 & 0.8960 & 4 & 3 & Slovenia & 0.6242 & 0.7492 & 29 & 25 \\
\hline Netherlands & 0.8097 & 0.9125 & 5 & 2 & Malta & 0.6129 & 0.7131 & 30 & 35 \\
\hline Norway & 0.8020 & 0.8593 & 6 & 8 & Columbia & 0.6125 & 0.6572 & 31 & 43 \\
\hline Denmark & 0.8772 & 0.8889 & 7 & 4 & Malaysia & 0.6101 & 0.6703 & 32 & 40 \\
\hline Australia & 0.7863 & 0.8390 & 8 & 12 & Czech Republic & 0.6060 & 0.6491 & 33 & 46 \\
\hline Spain & 0.7516 & 0.7770 & 9 & 23 & Chile & 0.6014 & 0.6769 & 34 & 39 \\
\hline France & 0.7510 & 0.8635 & 10 & 6 & Croatia & 0.5858 & 0.7328 & 35 & 30 \\
\hline Singapore & 0.7476 & 0.8474 & 11 & 10 & Unuguay & 0.5848 & 0.6315 & 36 & 50 \\
\hline Sweden & 0.7474 & 0.8599 & 12 & 7 & Latvia & 0.5826 & 0.6604 & 37 & 42 \\
\hline Bahrain & 0.7363 & 0.6946 & 13 & 36 & Italy & 0.5800 & 0.7190 & 38 & 32 \\
\hline New Zealand & 0.7311 & 0.8381 & 14 & 13 & Portugal & $0 . .5787$ & 0.7165 & 39 & 33 \\
\hline Germany & 0.7309 & 0.8079 & 15 & 17 & Barbados & 0.5714 & 0.6566 & 40 & 44 \\
\hline Belgium & 0.7225 & 0.7718 & 16 & 24 & Greece & 0.5708 & 0.6872 & 41 & 37 \\
\hline Japan & 0.7152 & 0.8019 & 17 & 18 & Cyprus & 0.5705 & 0.6508 & 42 & 45 \\
\hline Switzerland & 0.7136 & 0.8134 & 18 & 15 & Slovakia & 0.5639 & 0.6292 & 43 & 53 \\
\hline Finland & 0.6967 & 0.8505 & 19 & 9 & Bulgaria & 0.5590 & 0.6132 & 44 & 60 \\
\hline Estonia & 0.6965 & 0.7987 & 20 & 20 & Poland & 0.5582 & 0.6441 & 45 & 47 \\
\hline Ireland & 0.6866 & 0.7149 & 21 & 34 & Kazakhstan & 0.5778 & 0.6844 & 46 & 38 \\
\hline Iceland & 0.6697 & 0.7835 & 22 & 22 & Romania & 0.5479 & 0.6060 & 47 & 62 \\
\hline Liechtenstein & 0.6694 & 0.8264 & 23 & 14 & Argentina & 0.5467 & 0.6228 & 48 & 56 \\
\hline Austria & 0.6679 & 0.7840 & 24 & 21 & UAE & 0.5349 & 0.7344 & 49 & 28 \\
\hline Luxembourg & 0.6672 & 0.8014 & 25 & 19 & Kuwait & 0.5290 & 0.5960 & 50 & 63 \\
\hline
\end{tabular}

Table 4-1 below shows the only Arab countries in 2010 top 50 counties on the e-Government index are Bahrain, UAE and Kuwait. However, the 2012 United Nations survey, Kuwait has declined 13 positions $\left(65^{\text {th }}\right)$ compared to Saudi Arabia and Qatar (AlAthmay, 2013).

Moreover, table 4-2 shows that Kuwait suffered declines on e-Participation Index (EPI) of eGovernance EPI losing 37 positions. 
Table 4-2 Online Service Index

\begin{tabular}{|c|c|c|c|c|c|}
\hline \multirow[t]{2}{*}{ No. } & \multirow{2}{*}{ Country } & \multicolumn{2}{|c|}{2010} & \multicolumn{2}{|c|}{2012} \\
\hline & & Index Value & Global Rank & Index Value & Global Rank \\
\hline 1 & Bahrain & 0.7302 & 8 & 0.8627 & 10 \\
\hline 2 & United Arab Emirates & 0.2508 & 99 & 0.8627 & 12 \\
\hline 3 & Jordan & 0.5333 & 22 & 0.3922 & 100 \\
\hline 4 & Qatar & 0.2794 & 90 & 0.7386 & 27 \\
\hline 5 & Kuwait & 0.4603 & 36 & 0.5817 & 48 \\
\hline 6 & Saudi Arabia & 0.3111 & 75 & 0.7974 & 19 \\
\hline 7 & Lebanon & 0.2667 & 93 & 0.4771 & 77 \\
\hline 8 & Oman & 0.3683 & 55 & 0.6667 & 35 \\
\hline 9 & Syria & 0.0413 & 170 & 0.2288 & 156 \\
\hline 10 & Iraq & 0.1524 & 131 & 0.2876 & 146 \\
\hline 11 & Yemen & 0.0476 & 167 & 0.1765 & 175 \\
\hline 12 & Egypt & 0.5302 & 23 & 0.6013 & 42 \\
\hline 13 & Tunisia & 0.4825 & 30 & 0.4771 & 78 \\
\hline 14 & Libya & 0.1365 & 135 & 0.0000 & - \\
\hline 15 & Algeria & 0.0984 & 148 & 0.2549 & 149 \\
\hline 16 & Morocco & 0.2381 & 104 & 0.5425 & 56 \\
\hline 17 & Sudan & 0.1556 & 129 & 0.2549 & 151 \\
\hline 18 & Somalia & - & - & 0.1830 & 173 \\
\hline 19 & Djibouti & 0.0476 & 167 & 0.1961 & 165 \\
\hline 20 & Mauritania & 0.0889 & 150 & 0.0784 & 194 \\
\hline
\end{tabular}

This table shows the online service index for the top 20 ranked countries.

\subsection{Operationalization of the Variables}

Table 4-3 lists the related variables in the model, their original definitions, and operational definitions. After reviewing the literature, all constructs were defined with some modifications. However, the perceived support quality construct has not yet been examined empirically in the context of e-Government. Consequently, the current study captures the previous literature review in the IS field and identifies the main indicators used previously by academics to measure e-Service and facilitating conditions from IS literature.

Existing validated scales were adopted where possible for developing the survey instruments. Elsewhere, scales were adapted from previous studies by considering the research context as shown in Appendix A. All the items were measured using the 5-point Likert-scales. Given the fact that the official language of the State of Kuwait is Arabic, questionnaire items of this study have been translated accordingly. To provide adequate translation from English to Arabic, the decentring procedure (Prieto, 1992) was 
employed. Both the source and target versions contribute to the final version and the investigators (with the assistance of bilinguals) mutually agreed on the optimal translation considered to be equivalent to the source (Prieto, 1992).

Table 4-3 Original Definition and Operational Definitions of the Variables

\begin{tabular}{|c|c|c|}
\hline Variables & Original Definitions & Operational Definitions \\
\hline $\begin{array}{l}\text { Performance } \\
\text { Expectancy }\end{array}$ & $\begin{array}{l}\text { "The degree to which an } \\
\text { individual believes that using } \\
\text { the system will help him or her } \\
\text { to attain gains in job } \\
\text { performance" (Venkatesh et al., } \\
\text { 2003: 447) }\end{array}$ & $\begin{array}{l}\text { The degree to which citizens believe that } \\
\text { using government on-line services are } \\
\text { helpful, useful and practical more than } \\
\text { the tradition government services; (i.e. } \\
\text { accomplish the task quickly, saves time } \\
\text { and enhance effectiveness). }\end{array}$ \\
\hline $\begin{array}{l}\text { Effort } \\
\text { Expectancy }\end{array}$ & $\begin{array}{l}\text { "The degree of ease associated } \\
\text { with the use of the system" } \\
\text { (Venkatesh et al., 2003: 450) }\end{array}$ & $\begin{array}{l}\text { The degree of ease associated to the use } \\
\text { of government on-line services; (i.e. } \\
\text { interaction with the system is clear, } \\
\text { flexible and easy to use). }\end{array}$ \\
\hline $\begin{array}{l}\text { Social } \\
\text { Influence }\end{array}$ & $\begin{array}{l}\text { "The degree to which an } \\
\text { Individual perceives that } \\
\text { important others believe he or } \\
\text { she should use the new system" } \\
\text { (Venkatesh et al., 2003) }\end{array}$ & $\begin{array}{l}\text { The degree to which citizens perceive } \\
\text { that important people to them believe he/ } \\
\text { she should use government on-line } \\
\text { services. }\end{array}$ \\
\hline $\begin{array}{l}\text { Behavioural } \\
\text { Intention }\end{array}$ & $\begin{array}{l}\text { "The degree to which a person } \\
\text { has formulated conscious plans } \\
\text { to perform or not perform some } \\
\text { specified future behaviour" } \\
\text { (Venkatesh et al., 2008: 484) }\end{array}$ & $\begin{array}{l}\text { The degree to which citizens have } \\
\text { formulated conscious plans to continue } \\
\text { or not continue using government } \\
\text { website. }\end{array}$ \\
\hline $\begin{array}{l}\text { System } \\
\text { Quality }\end{array}$ & $\begin{array}{l}\text { "Measures the desirable } \\
\text { characteristics of an } \\
\text { Information System" (Petter, } \\
\text { DeLone and Mclean, 2008: 238). }\end{array}$ & $\begin{array}{l}\text { The quality of the desired functionality } \\
\text { and performance characteristics of } \\
\text { government website. }\end{array}$ \\
\hline $\begin{array}{l}\text { System } \\
\text { Satisfaction }\end{array}$ & $\begin{array}{l}\text { "How well the on-line } \\
\text { experience meets the needs of } \\
\text { site visitors" (Halaris et al., 2007: } \\
383) \text {. }\end{array}$ & $\begin{array}{l}\text { The satisfaction of citizens' perceptual } \\
\text { measure and evaluation of how well and } \\
\text { pleasant the on-line experience with } \\
\text { system quality interaction meets the } \\
\text { needs of citizens. }\end{array}$ \\
\hline $\begin{array}{l}\text { Information } \\
\text { Quality }\end{array}$ & $\begin{array}{l}\text { "Measures the desirable } \\
\text { characteristics of the system } \\
\text { outputs; that is, management } \\
\text { reports and Web pages" (Petter, } \\
\text { DeLone and Mclean, 2008: 239) }\end{array}$ & $\begin{array}{l}\text { The quality of the characteristics of } \\
\text { information provided by government } \\
\text { website. }\end{array}$ \\
\hline $\begin{array}{l}\text { Information } \\
\text { Satisfaction }\end{array}$ & $\begin{array}{l}\text { "How well the on-line } \\
\text { experience meets the needs of } \\
\text { site visitors" (Halaris et al., 2007: } \\
383 \text { ). }\end{array}$ & $\begin{array}{l}\text { The satisfaction of citizens' perceptual } \\
\text { measure and evaluation of how well and } \\
\text { pleasant the on-line experience with } \\
\text { information quality meets the needs of } \\
\text { citizens. }\end{array}$ \\
\hline $\begin{array}{l}\text { Perceived } \\
\text { Support } \\
\text { Quality }\end{array}$ & $\begin{array}{l}\text { It is the combination of } \\
\text { Facilitating Conditions from } \\
\text { (UTAUT) "the degree to which }\end{array}$ & $\begin{array}{l}\text { Citizens' judgement and perceptions of } \\
\text { the perceived support quality to which a } \\
\text { website facilitates efficiency and }\end{array}$ \\
\hline
\end{tabular}




\begin{tabular}{|c|c|c|}
\hline Variables & Original Definitions & Operational Definitions \\
\hline & $\begin{array}{l}\text { an individual believes that an } \\
\text { organizational and technical } \\
\text { infrastructure exists to support } \\
\text { use of the system" (Venkatesh et } \\
\text { al., 2003: 453), and Service } \\
\text { Quality from D\&M IS Success } \\
\text { Model "measures the quality of } \\
\text { the support that system users } \\
\text { receive from the IS department } \\
\text { and IT support personal" } \\
\text { (DeLone and McLean, 2003: 25). }\end{array}$ & $\begin{array}{l}\text { effectively delivery of e-Government } \\
\text { services from the overall support } \\
\text { delivered by the service provider; } \\
\text { regardless whether this support is } \\
\text { delivered by the IS/IT department and } \\
\text { personal support of government on-line } \\
\text { services, a new organizational unit, or } \\
\text { outsourced to an Internet service } \\
\text { provider (ISP). }\end{array}$ \\
\hline $\begin{array}{l}\text { Support } \\
\text { Satisfaction }\end{array}$ & $\begin{array}{l}\text { "Users' level of satisfaction with } \\
\text { reports, websites, and support } \\
\text { services" (Petter, DeLone and } \\
\text { Mclean, 2008: 239). }\end{array}$ & $\begin{array}{l}\text { The satisfaction of citizens' perceptual } \\
\text { measure and evaluation of how well and } \\
\text { pleasant the on-line experience with the } \\
\text { perceived support quality meets the } \\
\text { needs of citizens. }\end{array}$ \\
\hline
\end{tabular}

\subsection{Data Collection}

A pilot study was conducted to assess the reliability and validity of all construct measurement with 30 participants. During and after, items from the original scales were eliminated (PE8, EE5, EE6, and PSQ1) while others were modified to suit the current study. The participants for the main survey were selected based on convenient sample method and the survey materials were distributed using the following tools; paper-based, e-mail, and online survey tool.

The total number of citizens who participated in the survey was 1225 . The total of the citizens who completed the survey was 947 , with a response rate of 77.30 per cent. After deducting the outliers, the analysis of this study indicated that the data contained a few univariate outliers. Based on this criterion, 35 cases were deleted from the data using multiple regressions and data was reduced from 663 to 628 . The frequencies and percentages for the demographic variables describing the sample are displayed in Table 2. Most of the respondents were male (69.6 percent), married (65.3 percent) and Kuwait nationals (77.1 percent). The province with the biggest representation was Hawalli (34.4 percent), while the province with the smallest representation was Jahra ( 7.3 percent). More than half of the respondents were between 31 to 50 years old (56.5 percent), and more than half has a bachelor's or postgraduate degree (66.2 percent). We illustrate the demographics in table 4-4. 
Table 4-4 Demographic Information $(N=628)$

\begin{tabular}{|c|c|c|}
\hline Variable & Frequency & Percent \% \\
\hline \multicolumn{3}{|l|}{ Gender } \\
\hline Male & 437 & 69.6 \\
\hline Female & 191 & 30.4 \\
\hline \multicolumn{3}{|l|}{ Marital Status } \\
\hline Married & 410 & 65.3 \\
\hline Single & 218 & 34.7 \\
\hline \multicolumn{3}{|l|}{ Nationality } \\
\hline Kuwaiti & 484 & 77.1 \\
\hline Non-Kuwaiti & 144 & 22.9 \\
\hline \multicolumn{3}{|l|}{ Province } \\
\hline Assmah & 128 & 20.4 \\
\hline Hawally & 216 & 34.4 \\
\hline Farwania & 101 & 16.1 \\
\hline Ahmady & 75 & 11.9 \\
\hline Mubark & 62 & 9.9 \\
\hline Jahra & 46 & 7.3 \\
\hline \multicolumn{3}{|l|}{ Age group } \\
\hline 20 or under & 33 & 5.3 \\
\hline $21-30$ & 94 & 15.0 \\
\hline $31-40$ & 139 & 22.1 \\
\hline $41-50$ & 216 & 34.4 \\
\hline $51-60$ & 110 & 17.5 \\
\hline 61 and older & 36 & 5.7 \\
\hline \multicolumn{3}{|l|}{ Level of education } \\
\hline High school or below & 70 & 11.1 \\
\hline Diploma & 142 & 22.6 \\
\hline Bachelor & 249 & 39.6 \\
\hline Post graduate & 167 & 26.6 \\
\hline
\end{tabular}

\section{Data Analysis and Results}

\subsection{Instrument Validations}

Harman's (1967) single factor test was performed to examine the existence of common method bias among the variables in this study (Podsakoff, MacKenzie and Lee, 2003). The results of Harman's single factor test indicated that the sample lacked a significant presence of common method variance. Thus, there is no concern for common method bias in this study. As Anderson and Gerbing (1988) suggested, the combination of the measurement model and the structural model 
enables a comprehensive, confirmatory assessment of construct validity (convergent validity and discriminant validity). The authors used a two-step approach to perform SEM analysis. The first consisted of the measurement model, while the second is comprised of the structural model related to the dependent and independent variables of the study. The representation of latent variables, based on their relation to observed indicator is one of the major characteristics of SEM (Garson, 2012). Therefore, the first step provided a basis for assessing the validity of the structural theory and was performed using confirmatory factor analysis (CFA) using the interrelationships between observed indicators and latent variables. The second step was related to dependent and independent variables to test the hypotheses specified in the model.

\subsection{The Proposed Model}

The measurement model is estimated using the maximum likelihood (ML) estimation techniques provided by AMOS 18.0. To evaluate overall model fit for CFA and SEM, eight GOF indices, each describing the model fit from a different perspective, were reported for this study. The fit statistic and indices for the proposed measurement model are summarised in Table 5-1. Having an average fit, the proposed model did not fit the data well. The normed chi-square was below three (2.39), while the RMSEA (.04) and SRMR (.04), and TLI (.93) were within the acceptable range. However, the AGFI (.87), GFI (.89), and CFI (.94) were only close to the acceptable benchmarks. Further, the standardised residuals of a correct model should be less than the absolute value of two; whereas the absolute value of the highest standardised residual was high at 4.34. All factor loadings were evaluated at the $p<0.05$ level.

Table 5-1 Chi-square Results and GOF Indices for the Measurement Model

\begin{tabular}{|c|c|c|c|c|c|c|c|c|}
\hline \multicolumn{9}{|c|}{ Chi-square $(\chi 2)=1397.41, p=.000$} \\
\hline & \multicolumn{5}{|c|}{ Absolute Fit Measures } & \multicolumn{2}{|c|}{$\begin{array}{l}\text { Incremental } \\
\text { Fit Measures }\end{array}$} & $\begin{array}{l}\text { Parsimonious } \\
\text { Fit Measures }\end{array}$ \\
\hline Benchmark & $\mathrm{df}$ & $\begin{array}{r}\chi^{2} / \mathrm{df} \\
<3.00\end{array}$ & $\begin{array}{l}\text { GFI } \\
\geq .90\end{array}$ & $\begin{array}{l}\text { RMSEA } \\
<.05\end{array}$ & $\begin{array}{l}\text { SRMR } \\
\leq .08\end{array}$ & $\begin{array}{l}\text { TLI } \\
\geq .90\end{array}$ & $\begin{array}{l}\text { CFI } \\
\geq .95\end{array}$ & $\begin{array}{l}\text { AGFI } \\
\geq .90\end{array}$ \\
\hline Obtained & 584 & 2.39 & .89 & .04 & 0.4 & .93 & .94 & .87 \\
\hline
\end{tabular}


*Note: $\chi^{2}=$ Chi-square; $\mathrm{df}=$ degree of freedom; Normed chi-square or ratio of likelihood $\left(\chi^{2}\right)$ to degrees of freedom $=\chi^{2} / \mathrm{df} ; \mathrm{GOF}=$ Goodness of fit; GFI $=$ Goodness of fit index;

RMSEA = Root mean square error of approximation; SRMR = The Standardised Root Means Square Residual; TLI= Tucker-Lewis Index; CFI = Comparative fit index; AGFI - Adjusted goodness of fit index.

Since the AGFI and GFI values were below the acceptable benchmark, the measurement model was revised. Accordingly, modification was based on three criteria. First, only indicator variables with standardised factor loadings above .50 were retained (Hair et al., 2010). Second, as per Hair et al. (2010), indicator variables whose squared multiple correlations were below .30 were dropped. Third, indicator variables with high modification indices (MI) were deleted, as this indicated that the variables were cross-loading onto other constructs (Byrne, 2010). Based on these criteria, several variables were deleted. A list of these and the reasons for their deletion are displayed in Table 5-3 below.

Table 5-2 Items Deleted from the Proposed Measurement Model

\begin{tabular}{|c|c|c|}
\hline Reasons for their Deletion & $\begin{array}{l}\text { Deleted } \\
\text { Items }\end{array}$ & SMC/MI \\
\hline Squared multiple correlation below .30 & PE3R & .27 \\
\hline Squared multiple correlation below .30 & \multirow[t]{4}{*}{ SQ2 } & .24 \\
\hline SQ2 loaded onto BI2 & & 10.24 \\
\hline SQ2 loading on BI3 & & 13.55 \\
\hline SQ2 loading on PSQS3 & & 8.03 \\
\hline Squared multiple correlation below .30 & \multirow[t]{3}{*}{ IQ1 } & .25 \\
\hline IQ1 loaded onto BI3 & & 8.60 \\
\hline IQ1 loaded onto IQ2 & & 8.71 \\
\hline $\begin{array}{l}\text { Error term of PE1 (e11) highly correlated with error term of } \\
\text { PE2 (e12) }\end{array}$ & \multirow[t]{2}{*}{ PE1 } & 95.93 \\
\hline PE1 loaded onto PE2 & & 43.61 \\
\hline $\begin{array}{l}\text { Error term of PE2 (e12) highly correlated with error term PE4 } \\
\text { (e14) }\end{array}$ & \multirow[t]{3}{*}{ PE2 } & 18.72 \\
\hline PE2 loaded onto PE1 & & 53.52 \\
\hline PE2 loaded onto PE4 & & 10.45 \\
\hline Error of PSQ2 (e82) highly correlated error of IQ4 (e44) & \multirow[t]{4}{*}{ PSQ2 } & 8.80 \\
\hline PSQ2 loaded onto PE6 & & 13.10 \\
\hline PSQ2 loaded onto PSQS1 & & 10.37 \\
\hline PSQS3 loaded onto PSQ2 & & 12.12 \\
\hline Error of PSQ4 (e84) highly correlated error of PSQ5 (e85) & \multirow[t]{3}{*}{ PSQ4 } & 11.45 \\
\hline Error of PSQ4 (e84) highly correlated error of PSQS2 (e92) & & 10.96 \\
\hline PSQ4 loaded onto PE6 & & 18.39 \\
\hline
\end{tabular}




\begin{tabular}{lcc}
\hline $\begin{array}{l}\text { Error term of PE6 (e16) highly correlated with error term of } \\
\text { PE5 (e15) }\end{array}$ & 19.14 \\
\cline { 1 - 1 } PSQ4 loaded onto PE6 & & 18.40 \\
\hline PSQ6 loaded onto PE6 & 11.29 \\
PSQS2 loaded onto PE6 & 17.71 \\
\hline
\end{tabular}

*Note. SMC $=$ Squared Multiple Correlation. MI = Modification Index.

$* p<.05 . * * p<.01 . * * * p<.001$.

\subsection{The Revised Model}

Since the AGFI and GFI values were below the acceptable benchmark, the measurement model was revised. Accordingly, modification was based on three criteria. First, only indicator variables with standardised factor loadings above .50 were retained (Hair et al., 2010). Second, as per Hair et al. (2010), indicator variables whose squared multiple correlations were below .30 were dropped. Third, indicator variables with high modification indices (MI) were deleted, as this indicated that the variables were cross-loading onto other constructs (Byrne, 2010). Based on these criteria, several variables were deleted. The fit indices for the final model are summarised in Table 5 and the revised model fit the data well. The normed chi-square was below three, the RMSEA and the SRMR were very low, and the AGFI, CFI, and TLI values were above the acceptable benchmarks. Additionally, all standardised loading of items was .50, and all items' critical ratios (t-value) were greater than 1.96. Furthermore, the standard residual values were less than $( \pm 2.5)$ as recommended by (Hair et al., 2010). Therefore, all loadings were statistically significant and in the predicted direction. The fit statistic and indices for the revised measurement model are summarised in Table 5-4.

Table 5-3 Chi-square Results and GOF Indices for the Revised Measurement Models

\begin{tabular}{|c|c|c|c|c|c|c|c|c|}
\hline \multicolumn{9}{|c|}{ Chi-square $\left(\chi^{2}\right)=1397.41, p=.000$} \\
\hline & $\begin{array}{l}\text { Abs } \\
\text { df }\end{array}$ & $\begin{array}{l}\text { ute Fit } N \\
\qquad \alpha 2 / d f\end{array}$ & $\begin{array}{l}\text { asures } \\
\text { GFI }\end{array}$ & RMSEA & SRMR & $\begin{array}{l}\text { Incree } \\
\text { Fit M } \\
\text { TLI }\end{array}$ & $\begin{array}{l}\text { ental } \\
\text { asures } \\
\text { CFI }\end{array}$ & $\begin{array}{l}\text { Parsimonious } \\
\text { Fit Measures } \\
\text { AGFI }\end{array}$ \\
\hline Benchmark & & $<3.00$ & $\geqslant .90$ & $<.05$ & $\leqslant .08$ & $\geqslant .90$ & $\geqslant .95$ & $\geqslant .90$ \\
\hline $\begin{array}{l}\text { Obtained } \\
\left.\text { ( } 1^{\text {st }} \text { run }\right)\end{array}$ & 584 & 2.39 & .89 & .04 & .04 & .93 & .94 & .87 \\
\hline
\end{tabular}




\begin{tabular}{l|lllll|lll}
\hline $\begin{array}{l}\text { Modified } \\
\text { CFA }\end{array}$ & 332 & 2.10 & .93 & .04 & .04 & .96 & .96 & .91 \\
$\begin{array}{l}\text { Model } \\
\left(2^{\text {nd }} \text { run }\right)\end{array}$ & & & & & & & & \\
\hline
\end{tabular}

*Note: $\chi^{2}=$ Chi-square; $\mathrm{df}=$ degree of freedom; Normed chi-square or ratio of likelihood $(\chi 2)$ to degrees of freedom $=\chi 2 / \mathrm{df}$; GOF $=$ Goodness of fit; GFI = Goodness of fit index;

RMSEA = Root mean square error of approximation; SRMR $=$ The Standardised Root Means Square Residual; TLI $=$ Tucker-Lewis Index; CFI = Comparative fit index; AGFI - Adjusted goodness of fit index.

\subsection{Reliability of Constructs}

Cronbach's alpha, the composite reliability and the average variance extracted were used to measure the reliability of the constructs. Constructs are deemed reliable when Cronbach's alpha is .70 or higher (Nunnally and Bernstein, 1994), the composite reliability exceeds the criterion of .70 , as suggested by Hair et al. (2010), and the average variance extracted is above .50, as suggested by (Bagozzi, Youjae and Phillips, 1991). As shown in Table 5-5, all estimation values of the constructs were above the recommended cut-off point; that is, composite reliabilities exceeded the criterion of .70 , indicating strong reliability and high internal consistency in measuring relationships in the model. This suggested strong construct validity as recommended by (Hair et al., 2010). In addition, the average variance extracted values were all above .50. Therefore, all constructs were reliable.

Table 5-4 Reliability Measures for the Constructs $(N=628)$

\begin{tabular}{llll}
\hline Construct & $\begin{array}{l}\text { Cronbach's } \\
\text { Alpha }\end{array}$ & $\begin{array}{l}\text { Composite } \\
\text { Reliability }\end{array}$ & $\begin{array}{l}\text { Average Variance } \\
\text { Extracted }^{2}\end{array}$ \\
\hline Significant Value & $\geq .70$ & $>.70$ & $>.50$ \\
\hline Information Quality & .85 & .85 & .66 \\
\hline Information Satisfaction & .86 & .87 & .69 \\
\hline System Quality & .77 & .71 & .52 \\
\hline System Satisfaction & .86 & .87 & .69 \\
\hline Performance Expectancy & .84 & .77 & .53 \\
\hline Effort Expectancy & .80 & .81 & .58 \\
\hline Social Influence & .82 & .82 & .70 \\
\hline Perceived Support Quality & .87 & .87 & .68 \\
\hline Support Satisfaction & .85 & .84 & .66 \\
\hline Behaviour Intention & .83 & .87 & .64 \\
\hline$*$ Notes: & & & \\
\hline
\end{tabular}




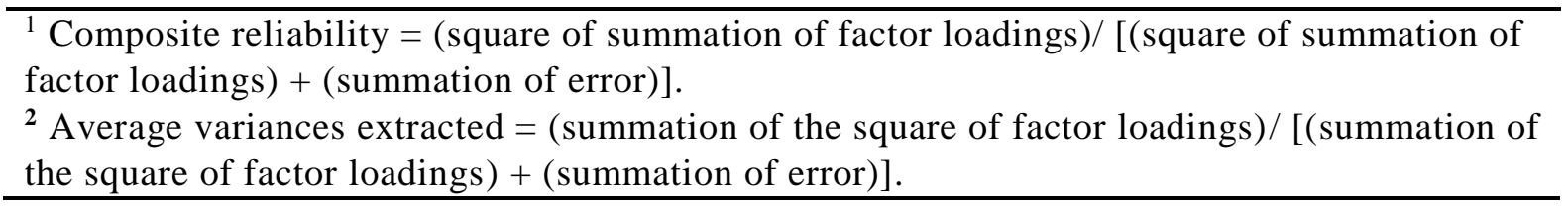

\subsection{Convergent and Discriminant Validity of Constructs}

One of the main advantages of CFA is its ability to assess the construct validity of the proposed measurement theory (Kline, 2011; Hair et al., 2010). The findings reveal that all standardised factor loadings were statistically significant and more than .50. All squared multiple correlations were also greater than .30; thus, the measures demonstrated convergent validity.

Discriminant validity was assessed by comparing the absolute value of the correlations between the constructs with the square root of the average variance extracted by a construct. The correlations and the square root of the average variance extracted by each of the constructs are presented in Table 5-6. The square root of the average variance extracted value for all the constructs were higher than its correlations with all the other constructs (Kline, 2011; Hair et al., 2010). Thus, all constructs had discriminant validity.

Table 5-5 Discriminant Validity for the Revised Measurement Model ( $N=628$ )

\begin{tabular}{lllllllllll}
\hline & SI & PE & PSQS & BI & EE & PSQ & SQS & IQS & SQ & IQ \\
\hline SI & .84 & & & & & & & & & \\
PE & .23 & .72 & & & & & & & & \\
PSQS & -.18 & .02 & .81 & & & & & & & \\
BI & .17 & .48 & .09 & .80 & & & & & & \\
EE & .24 & .71 & .02 & .55 & .76 & & & & & \\
PSQ & -.07 & .20 & .52 & .38 & .21 & .83 & & & & \\
SQS & -.04 & .28 & .45 & .43 & .36 & .69 & .83 & & & \\
IQS & -.01 & .33 & .38 & .43 & .38 & .65 & .76 & .83 & & \\
SQ & .03 & .34 & .40 & .38 & .44 & .49 & .71 & .53 & .72 & \\
IQ & -.04 & .28 & .32 & .30 & .38 & .45 & .59 & .76 & .50 & .81 \\
\hline
\end{tabular}

*Note $: \mathrm{SI}=$ social influence; $\mathrm{PE}=$ performance expectancy; $\mathrm{PSQS}=$ support satisfaction; $\mathrm{BI}=$ behaviour intention; $\mathrm{EE}=$ effort expectancy; $\mathrm{PSQ}=$ perceived support quality; $\mathrm{SQS}=$ system satisfaction; IQS= information satisfaction; $\mathrm{SQ}=$ system quality; $\mathrm{IQ}=$ information quality.

The fit statistic and indices for the proposed structural model are summarised in Table 5-7. The results indicate that the hypothesised structural model provided a good fit to the data. Although the likelihood ratio chi-square $\left(\chi^{2}=874.05 ; \mathrm{df}=361\right.$; 
$\mathrm{p}=.000)$ was significant $(\mathrm{p}<.001)$, other fit measures showed that the model adequately fits the observed data. The absolute fit measures (GFI and RMSEA) were .91 and .04 respectively, indicating a good fit of model. The incremental fit measures (TLI and CFI) were .94 and .95 respectively, which were above the minimum requirement; thereby, showing adequate fit and the parsimony fit measure (AGFI) of .90, which was also above the cut-off point of >.90). In addition to these indices, the $\chi^{2} / \mathrm{df}=2.42$ was within the threshold level $\left(1.0<\chi^{2} / \mathrm{df}<3.0\right)$, thus supporting these findings.

Table 5-6 Chi-square Results and GOF Indices for the Structural Model

\begin{tabular}{l} 
Chi-square $(\chi 2)=874.05, p=.001$ \\
\hline \multicolumn{7}{c}{ Absolute Fit Measures } \\
\end{tabular}

\subsection{Assessment the Model Fit}

The fit statistic and indices for the proposed measurement model are summarised in Table 5.8, while the model is depicted in Figure 5-7. The results indicate that the hypothesised structural model provided a good fit to the data. Although the likelihood ratio chi-square $\left(\chi^{2}=874.05 ; \mathrm{df}=361 ; \mathrm{p}=.000\right)$ was significant $(\mathrm{p}<.001)$, other fit measures showed that the model adequately fits the observed data. The absolute fit measures (GFI and RMSEA) were .91 and .04 respectively, indicating a good fit of model. The incremental fit measures (TLI and CFI) were .94 and .95 respectively, which were above the minimum requirement; thereby, showing adequate fit and the parsimony fit measure (AGFI) of .90 , which was also above 
the cut-off point of $>.90)$. In addition to these indices, the $\chi^{2} / \mathrm{df}=2.42$ was within the threshold level $\left(1.0<\chi^{2} / \mathrm{df}<3.0\right)$, thus supporting these findings.

Table 5-7 Chi-square Results and GOF Indices for the Structural Model

\begin{tabular}{|c|c|c|c|c|c|c|c|c|}
\hline \multicolumn{9}{|c|}{ Chi-square $(\alpha 2)=874.05, p=.001$} \\
\hline & \multirow{2}{*}{\multicolumn{5}{|c|}{ Absolute Fit Measures }} & \multirow{2}{*}{\multicolumn{2}{|c|}{$\begin{array}{l}\text { Incremental } \\
\text { Fit Measures }\end{array}$}} & Parsimonious \\
\hline & & & & & SRMR & & $\begin{array}{l}\text { asures } \\
\text { CFI }\end{array}$ & $\begin{array}{l}\text { Fit Measures } \\
\text { AGFI }\end{array}$ \\
\hline Benchmark & & $<3.00$ & $\geqslant .90$ & $<.05$ & $\leqslant .08$ & $\geqslant .90$ & $\geqslant .95$ & $\geqslant .90$ \\
\hline Obtained & 361 & 2.42 & .91 & .04 & .08 & .94 & .95 & .90 \\
\hline
\end{tabular}

\subsection{Hypotheses Testing}

The parameter estimates were used to create the estimated population covariance matrix for the structural model. To test the structural model, the covariance matrix among the constructs was applied. Using the path estimates and CR values, there are 13 causal paths in this study. However, we focus on three hypothesised paths that are related to perceived support quality. All three hypotheses are statistically significant and in the right prediction, excluding the causal path between social influence and behaviour intention to use e-Government systems. The path coefficients and their critical ratios are presented in Table 5-8.

Table 5-8 Path Coefficients for the Proposed Structural Model

\begin{tabular}{|c|c|c|c|c|c|c|c|c|}
\hline Hypothesis & Hypothesis & d Path & & Estimate & S.E. & C.R. & $\beta$ & $\mathrm{P}$ \\
\hline $\mathrm{H} 1$ & $\begin{array}{l}\text { Support } \\
\text { Satisfaction }\end{array}$ & $<--$ & $\begin{array}{l}\text { Perceived } \\
\text { Support } \\
\text { Quality } \\
\end{array}$ & .53 & .05 & 10.89 & .49 & $* * *$ \\
\hline $\mathrm{H} 2$ & $\begin{array}{l}\text { Behaviour } \\
\text { Intention }\end{array}$ & $<---$ & $\begin{array}{l}\text { Support } \\
\text { Satisfaction }\end{array}$ & 1.35 & .21 & 6.49 & .27 & $* * *$ \\
\hline $\mathrm{H} 3$ & $\begin{array}{l}\text { System } \\
\text { Satisfaction }\end{array}$ & $<---$ & $\begin{array}{l}\text { Support } \\
\text { Satisfaction }\end{array}$ & 2.70 & .22 & 12.44 & .48 & $* * *$ \\
\hline
\end{tabular}

Note $:$ Estimate $=$ standardized regression weights (path estimate), S.E = standard error, C.R. $=$ critical ratio $(t$-value $), \mathrm{P}=$ critical $(p$-value $)=$ significance value .

$* \mathrm{p}<0.05 ; * * \mathrm{p}<0.01 ; * * * \mathrm{p}<0.001$

The squared multiple correlations $\left(\mathrm{R}^{2}\right)$ for the endogenous constructs are presented in Table 5-9. The $\left(\mathrm{R}^{2}\right)$ is a statistical measure of how well a regression line approximates real data points and a descriptive measure between zero and one, indicating how good 
one term is at predicting another (Hair et al., 2010; Brown, 2006). In other words, the closer its $\left(\mathrm{R}^{2}\right)$ value is to one, the greater the ability of the construct to predict a trend (Brown, 2006). The 40 percent of the variance among the factors of support satisfaction, system satisfaction, information quality, effort expectancy and performance expectancy were explained by behavioural intention to use an eGovernment system.

Table 5-9 Proportion of Variance Accounted for by the Predictors of the Endogenous Constructs

\begin{tabular}{l|l}
\hline Construct & $\mathrm{R}^{2}$ \\
\hline Perceived Support Satisfaction & .24 \\
\hline System Satisfaction & .76 \\
\hline Information Quality & .42 \\
\hline Effort Expectancy & .14 \\
\hline Information Satisfaction & .74 \\
\hline Performance Expectancy & .60 \\
\hline Behaviour Intention & .40 \\
\hline
\end{tabular}

\subsection{Testing Mediation}

Perceived support quality was significantly correlated with support satisfaction ( $\mathrm{p}$ $=.001)$ and marginally correlated with behavioural intent $(p=.069)$. Support satisfaction was significantly correlated with behavioural intent $(p=.001)$. The model without the direct effect of perceived support quality to behavioural intent fits well. The change in chi-square between the model without the direct effect and the model with the direct effect was not statistically significant $\left(\Delta \chi^{2}=3.61\right.$, NS $)$. Therefore, support satisfaction mediated fully the effect of perceived support quality on behavioural intent.

System quality was significantly correlated with system satisfaction $(p=.001)$ and significantly correlated with effort expectancy $(\mathrm{p}=.001)$. System satisfaction was significantly correlated with effort expectancy $(p=.001)$. The model without the direct effect of system quality to effort expectancy fits well. The change in chisquare between the model without the direct effect and the model with the direct effect was statistically significant $\left(\Delta \chi^{2}=35.51, p<.001\right)$. 


\subsection{Results of Testing the Hypotheses}

Table 5-10 presents the results, which indicate that the main model estimations revealed that three hypotheses were positively significant. It means that the proposed hypotheses are supported. The path coefficients were above the 1.96 critical values at the significant level $\mathrm{p} \leq .05$. Thus, all path coefficients were statistically significant and in the predicted direction. The final structural model with the standardised path coefficients is presented in Figure 5-1.

Figure 5-1 Structural Model with Standardised Path Coefficients

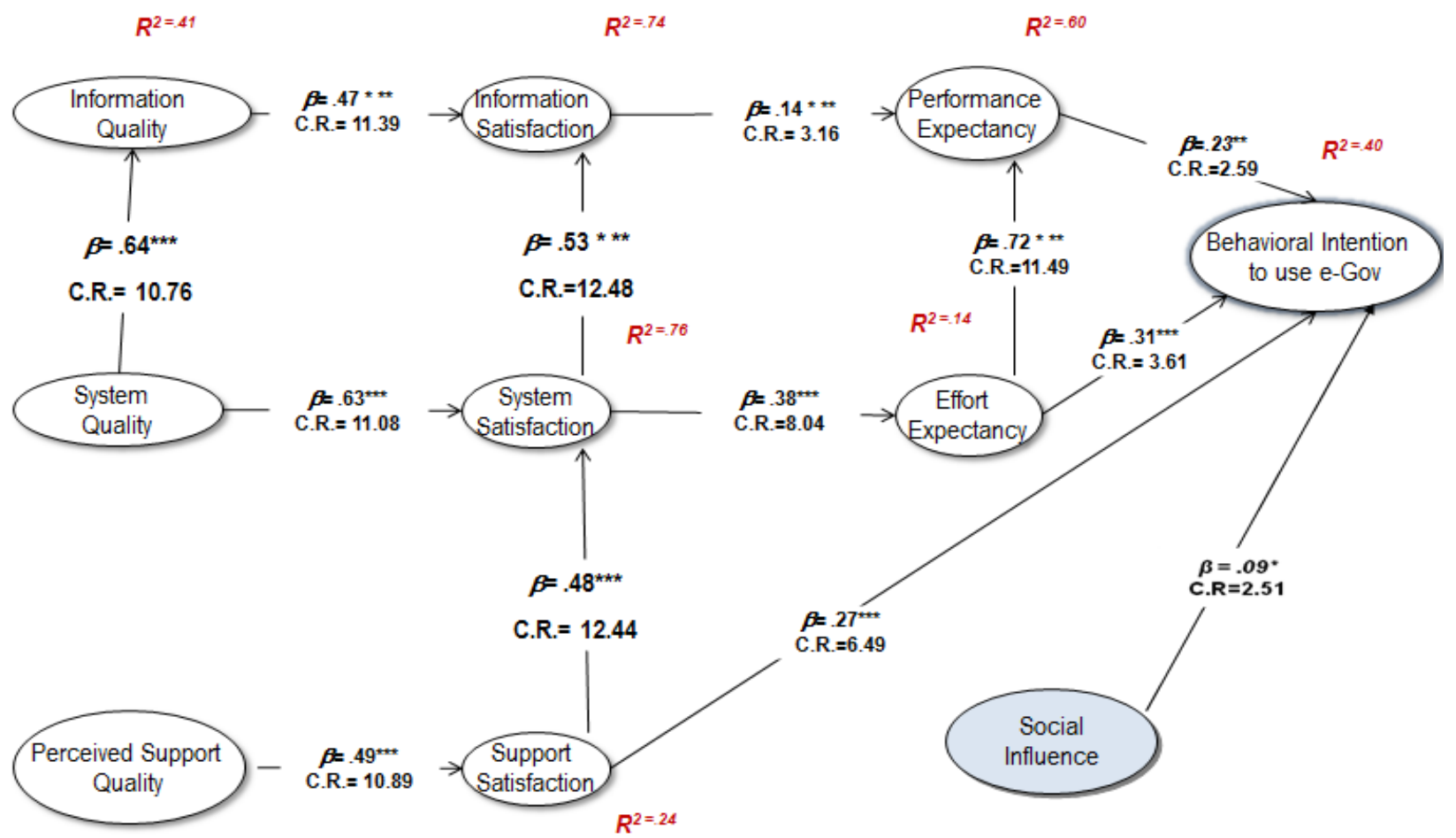


Table 5-100 Findings of The Research Hypotheses

\begin{tabular}{llllll} 
No. & Summary of Research Hypotheses & Results & $\boldsymbol{\beta}$ & Sig. \\
H1 & $\begin{array}{l}\text { Perceived support quality is significantly } \\
\text { related to support satisfaction of e- } \\
\text { Government system. }\end{array}$ & Accepted & & $* * *$ \\
\hline H2 & $\begin{array}{l}\text { Support satisfaction is significantly related to } \\
\text { behavioural intention to use e-Government } \\
\text { system. }\end{array}$ & & & \\
\hline H3 & $\begin{array}{l}\text { Support satisfaction is significantly related to } \\
\text { system satisfaction. }\end{array}$ & Accepted & .48 & $* * *$ \\
\hline
\end{tabular}

\section{Conclusion}

The aim of the current study was to reveal role of perceived support quality and support satisfaction towards intention to use and usage in the context of eGovernment in developing countries. The perceived support quality delivered by the service providers, government administrations, and the IT personnel indicated its significance as a critical factor in explaining the behaviour intention and usage of e-Government services. The perceived support quality had a significant influence on support satisfaction. It indicates that the higher citizens perceive the quality of the support received online, the greater their satisfaction with the support offered; thus, they become inclined to use the e-Government systems.

The finding in our study is threefold. Firstly, it demonstrates that research on eGovernment adoption can and should consider both streams of literature; that is, the user-satisfaction literature and the technology acceptance literature. Wixom and Todd (2005) built a theoretical logic model that links object-based beliefs into a system with behavioural-based beliefs in predicting users' usage of specific software. However, because of the nature of e-Government systems, which is based on virtual interactions, the prior study lacks the third dimension of DeLone and McLean's IS success model: service quality. In e-Government environments, the construct e-Service should be included to capture the technical services provided by the authorities, particularly when citizens seek an online help. Secondly, to the best of the authors' knowledge, the integrated model of Wixom and Todd was not validated previously in an e-Government setting. Wixom and Todd's model 
represents a theoretical integration of user satisfaction and technology acceptance theories. The strength of the integrated model lies in its ability to guide both IT design of governments' Websites (object-based attitudes and beliefs expressed in the quality of dimension of DeLone and McLean's IS success model), which affects the behavioural beliefs that are captured in (UTAUT constructs) and predict usage behaviours towards system usage. Thus, validating the concept from user satisfaction literature and technology acceptance literature into a single unified model, empirically provide the conceptual understanding of the difference between object-based beliefs and attitudes and behavioural beliefs and attitudes toward use as suggested by (Wix om and Todd, 2005).

The study supports that the precision of object-based beliefs in e-Government settings should not be based on the direct relationships of these factors to explain behaviour intentions and usage of such systems. However, such relationships can only be understood by examining proper mediating factors related to behavioural beliefs towards use, and behavioural intention as indicated in the UTAUT model. Thus, integrating object-based beliefs represented in DeLone and McLean's IS success model and behavioural beliefs, as in UTAUT and TAM, yields a better understating of behavioural intentions to use e-Government systems. Accordingly, from a theoretical view, the perceived support quality factor embedded in Wixom and Todd's model enriches the model to the prediction of e-Government adoption.

In practice, the proposed model provides decision makers in government organisations of developing countries with an appropriate approach to determining which factors require attention in order to reap the highest benefits from eGovernments' projects, while ensuring that citizens accept the modern way of interacting via 'e-Government systems.' According to the proposed model, the most important issues that need attention when implementing an on-line G2C system are: Performance Expectancy, which is influenced by satisfaction generated by the information in e-Government systems; Effort Expectancy, which is the outcome of the satisfaction of the characteristics of the system; and finally, the support citizens experienced while interacting with such systems. Citizens will have more positive attitudes and will value online services more when they perceive that they could interact within the system with more confidence. The study 
also implies that the government organisations should keep improving the quality of their websites. Undoubtedly, providing up-to-date, complete, and relevant information to citizens about online services, assuring easy navigation, quick response time, availability of the link-reliability and the perceptions of support, are proven in this study to be the most critical factors in e-Government adoption literature.

The proposed model offers managers a new perspective for dealing with eGovernment system acceptance by suggesting that the perceived support quality perceived by citizens is one of the best indicators of adopting and using such systems. The results also indicate that managers should pay less attention to the Social Influence factor and consider improving the quality of online services being offered. More emphasis should be placed on ensuring that the citizens use the technology efficiently and effectively, as user satisfaction leads to a positive impact on behaviour intention to use the systems.

In fact, the support provided to users emerged as one of the most critical factors in an early study of end-users' computing (Bergeron et al., 1990). Later, due to the lack of in-person communication between users and website managers, service quality has become a vital issue within the web environment. Likewise, evidence was provided in this study to support the view of the perceived support quality, which included the concept of service quality as an antecedent to behavioural beliefs by affecting object-based beliefs, mainly in developing countries.

Despite the findings of this study, the results should be discussed in the context of its limitations. First, convenient sampling techniques were applied in this study instead of random sampling. Though 74.2 percent of Kuwait's population have access to the Internet (Internet World Stats, 2012), the usage of e-Government is not prevalent in Kuwait. Thus, it was hard to use users of e-Government services in Kuwait as a sampling framework. Second, the sample size covered the most experienced users of the e-Government systems, especially after making the decision to distribute the survey online. 
There is no doubt that numerous factors may influence behavioural intention to use e-Government systems in both developed and developing countries. In particular, a replication of the current study might yield different results in a mandatory setting. To date, using e-Government services is more voluntary than mandatory. And this study investigated the relationships in a voluntary setting. Thus, it will be interesting to compare the relationships between voluntary and mandatory setting. Moreover, the framework could be used for mobile government to test its validity in different applications other than the Internet. 


\section{References}

Agourram, H. (2009). Defining information system success in Germany. International Journal of Information Management, 29(2), 129-137.

Ahn, T., Ryu, S., \& Han, I. (2004). The Impact of the Online and Offline Features on the User Acceptance of Internet Shopping Malls. Electronic Commerce Research and Applications, 3(4), 405-420.

Al-adaileh, R. M. (2009). An Evaluation of Information Systems Success: A User Perspective - the Case of Jordan Telecom Group. European Journal of Scientific Research, 37(2), 226-239.

Al-Hujran, O., Al-dalahmeh, M., \& Aloudat, A. (2011). The Role of National Culture on Citizen Adoption of eGovernment Services: An Empirical Study. Electronic Journal of eGovernment, 9(2), 93-106.

Al-Shafi, S., \& Weerakkody, V. (2009). Understanding Citizens' Behavioural Intention in the Adoption of e-Government Services in the State of Qatar. Paper presented at the 17th European Conference on Information Systems (ECIS 2009), Verona, Italy.

Al-Sobhi, F., Weerakkody, V., \& Al-Shafi, S. (2010). The Role of Intermediaries in Facilitating E-Government Diffusion in Saudi Arabia, European and Mediterranean Conference on Information Systems (EMCIS2010)). Abu Dhabi, UAE.

AlAwadhi, S., \& Morris, A. (2008, January 7-10). The Use of the UTAUT Model in the Adoption of E-Government Services in Kuwait. Paper presented at the 41st Annual Hawaii International Conference on System Sciences, Waikoloa, Big Island, Hawaii.

AlAwadhi, S., \& Morris, A. (2009). Factors Influencing the Adoption of E-government Services. Journal of Software, 4(6), 584-590.

Anderson, J. C., \& Gerbing, D. W. (1988). Structural Equation Modeling in Practice: A Review and Recommended Two-Step Approach. Psychological Bulletin, 103(3), 411-423.

At the Dawn of e-Government: The Citizen as Customer. (2000). NY, New York: Deloitte Consulting and Deloitte \& Touche. 
Auditing e-Government: Life-cycle Risks and Setting up a Database. (2003). USA.

Basettihalli, Rangamani; Kim, Hee-Woong; Lee, Hyun-Lyung; Noh, Seung-Eui (2010) Structural Analysis of e-Government in India, Asia pacific journal of information systems, v.20, no.2, pp.1-21.

B. Ives, Olson, M. H., \& Baroudi, J. J. (1983). The Measurement of User Information Satisfaction. ACM Request Permissions, 26(10), 785-793.

Beyond Economic Growth Student Book: Glossary. (2004, 20 May 2010). from http://www.worldbank.org/depweb/english/beyond/global/glossary.html

Bhattacharya, D., Gulla, U., \& Gupta, M. P. (2010). E-Service Quality Model for Indian Government Portals: Citizens' Perspective. Journal of Enterprise Information Management, 25(3), 246-271.

Bressolles, G., \& Nantel, J. (2008). The Measurement of Electronic Service Quality: Improvements and Application. International Journal of E•Business Research, 4(3), 1-19.

Byrne, B. M. (2010). Structural Equation Modeling with AMOS: Basic Concepts, Applications, and Programming (2nd ed.). New York, NY, U.S.A: Routledge, Taylor and Francis Group.

Carter, L., \& Bélanger, F. (2005). The Utilization of e-Government Services: Citizen Trust, Innovation and Acceptance Factors. Information Systems Journal, 15(1), 5-26.

Chatfield, A. T., \& Alhujran, O. (2009). A Cross-Country Comparative Analysis of EGovernment Service Delivery among Arab Countries. Information Technology for Development, 15(3), 151-170.

Chau, P. Y. (2001). Influence of Computer Attitude and Self-Efficacy on IT Usage Behavior. Journal of End User Computing, 13(1), 26-33.

Cruza, Ruth Angelie B.; Lee, Hong Joo (2016). A Socio-Technical Model for Open Government Data Research, Asia pacific journal of information systems, v.26, no.3, pp.339366. 
Davis, F. F. (1989). Perceived Usefulness, Perceived Ease of Use, and User Acceptance of Information Technology. MIS Quarterly, 13(3), 319-340.

DeLone, W. H., \& McLean, E. R. (1992). Information Systems Success: The Quest for the Dependent Variable. Information Systems Research, 3(1), 60-95.

DeLone, W. H., \& McLean, E. R. (2003). The DeLone and McLean Model of Information Systems Success: A Ten-Year Update. Journal of Management Information Systems, 19(4), 930.

DeLone, W. H., \& McLean, E. R. (2004). Measuring e-Commerce Success: Applying the DeLone \& McLean Information Systems Success Model. International Journal of Electronic Commerce, 9(1), 31-47.

Dwivedi, Y. K., \& Williams, M. D. (2008). Demographic Influence on UK Citizens' EGovernment Adoption. Electronic Government, An International Journal, 5(3), 261-274. .

E-Government Survey 2010: Leveraging e-Government at a Time of Financial and Economic Crisis. (2010). New York,USA: United Nations, UN Publishing Section.

F. D. Davis, Bagozzi, P., \& Warshaw, P. R. (1989). User Acceptance of Computer Technology: A Comparison of Two Theoretical Models. Management Science, 35(8), 982-1003.

Galpaya, H., Samarajiva, R., \& S. Soysa, S. (2007). Taking e-Government to the Bottom of the Pyramid: dial-a-Gov?, 1st International Conference on Theory and Practice of Electronic Governance (pp. 223-241). Macao, China: ACM.

Garson, G. D. (2012). Canonical Correlation: Structural Equation Modeling. Asheboro, NC: Statistical Associates Publishers.

Gautrin, H. F. (2004). Connecting Quebec to its Citizens. Québec.

The Good, the Bad and the Inevitable: The Pros and Cons of E-Government. (2008). The Economist. 
Gorla, N., Somers, T. M., \& Wong, B. (2010). Organizational Impact of System Quality, Information Quality, and Service Quality. The Journal of Strategic Information Systems, 19(3), 207-228.

Gupta, B., Dasgupta, S., \& Gupta, A. (2008). Adoption of ICT in a Government Organization in a Developing Country: An Empirical Study. The Journal of Strategic Information Systems, $17(2), 140-154$.

Gupta, D. N. (2007). Citizen-centric Approach for e-Governance. In A. Agarwal \& V. V. Ramana (Eds.), Foundations of E-government-5th International Conference on E-Government (pp. 28-30). Hyderabad, India.

Gupta, M. P., \& Debashish, J. (2003). E-Government Evaluation: A Framework and Case Study. Government Information Quarterly, 20(4), 365-387.

Hair, J. F., Black, W. C., Babin, B. J., \& Anderson, R. (2010). Multivariate Data Analysis: A Global Perspective (7th ed.). USA: Pearson Education.

Halaris, C., Magoutas, B., Papadomichelaki, X., \& Mentzas, G. (2007). Classification and synthesis of quality approaches in e-government services. Internet Research, 17(4), 378-401.

Heinze, N., \& Hu, Q. (2005). E-Government Research: A Review via the Lens of Structuration Theory, Ninth Pacific Asia Conference on Information Systems (PACS2005) (pp. 891-904. ).

Hoffman, D. K. (2003). Marketing + MIS = E-Service. Communications of the ACM, 46(6), 53-55.

Horst, M., Kuttschreuter, M., \& Gutteling, J. M. (2007). Perceived Usefulness, Personal Experiences, Risk Perception and Trust as Determinants of Adoption of E-Government Services in The Netherlands. Computers in Human Behavior, 23(4), 1838-1852.

Hu, G., Pan, W., Lu, M., \& Wang, J. (2009). The widely shared definition of e-Government: An exploratory study. The Electronic Library, 27(6), 968-985.

Iivari, J. (2005). An Empirical Test of the DeLone-Mclean Model of Information System Success. The DATA BASE for Advances in Information Systems, 36(2), 8-27. 
The Internet Big Picture: World Internet Users and Population Stats. (2012). Retrieved January 8, 2013, from http://www.internetworldstats.com/stats.htm

Kanat, I. E., \& Özkan, S. (2009). Explaining Citizen Adoption of Government to Citizen Services: A Model Based on Theory of Planned Behaviour (TBP). Transforming Government: People,Process and Policy, 3(4), 406-419.

Kim, Y., Chun, J., \& Song, J. (2009). Investigating the Role of Attitude in Technology Acceptance from an Attitude Strength Perspective. International Journal of Information Management, 29(1), 67-77.

Kline, R. B. (2011). Principles and Practice of Structural Equation Modeling (3rd ed.). New York: The Guilford Press.

Knutsen, L. A. (2005). M-Service Expectancies and Attitudes: Linkages and Effects of First Impressions. Paper presented at the 38th Annual Hawaii International Conference on System Sciences (HICSS'05).

Kolsaker, A., \& Lee, L. (2007). 'Mind the Gap II': E-Government and E-Governance. EGOV, LNCS 4656, 35-43.

Mathieson, K. (1991). Predicting User Intentions: Comparing the Technology Acceptance Model with the Theory of Planned Behavior

Information Systems Research, 2(3), 173-191.

Misra, D. C. (2008). Ten Guiding Principles for E-government. New York: United Nations Public Administration Network (UNPAN).

Molla, A., \& Licker, P. S. (2001). E-Commerce System Success: An Attempt to Extend and Respecify the DeLone \& McLean Model of IS Success. Journal of Electronic Commerce Research, 2(4), 131-141.

Ozkan, S., \& Kanat, I. E. (2011). E-Government Adoption Model Based on Theory of Planned Behavior: Empirical Validation. Government Information Quarterly, 28(4), 503-513. 
Petter, S., DeLone, W., \& Mclean, E. (2008). Measuring Information Systems Success: Models, Dimensions, Measures, and Interrelationships. European Journal of Information Systems, 17(3), 236-264.

Phang, C. W., Sutanto, J., Kankanhalli, A., Li, Y., Tan, B. C. Y., \& Teo, H. H. (2006). Senior Citizens' Acceptance of Information Systems: A Study in the Context of e-Government Services. IEEE Transactions on Engineering Management, 53(4), 555-570.

Prieto, A. J. (1992). A Method for Translation of Instruments to other Languages. Adult Education Quarterly, 43(1), 1-14.

Pudjianto, Boni; Zo, Hangjung; Ciganek, Andrew P.; Rho, Jae-Jeung. (2011). Determinants of E-Government Assimilation in Indonesia: An Empirical Investigation Using a TOE Framework, Asia pacific journal of information systems, v.21, no.1, pp.49-80.

Rai, A., Lang, S. S., \& Welker, R. B. (2002). Assessing the Validity of IS Success Models: An Empirical Test and Theoretical Analysis. Information Systems Research, 13(1), 50-69.

Ronaghan, S. A. (2002). Benchmarking E-Government: A Global Perspective. New York: United Nations/American Society for Public Administration.

Sahu, G. P., \& Gupta, M. P. (2007). Users Acceptance of E-Government: A Study of Indian Central Excise. International Journal of Electronic Government Research, 3(3), 1-21.

Schuppan, T. (2009). E-Government in Developing Countries: Experiences from Sub-Saharan Africa. Government Information Quarterly, 26(1), 118-127.

Seddon, P. B. (1997). A Respecification and Extension of the DeLone and McLean Model of IS Success. INFORMATION SYSTEMS RESEARCH, 8(3), 240-253.

Seddon, P. B., \& Kiew, M. (1996). A Partial Test and Development of DeLone and McLean's Model of Is Success. Australian Journal of Information system (AJIS), 4(2), 90-109.

Shahkooh, K., Abbasi, S., Fatemeh, \& Abdollahi, A. (2008). A Proposed Model for EGovernment Maturity. IEEE Computer Society, 1-5. 
Sharifi, H., \& Zarei, B. (2004). An Adaptive Approach for Implementing e-Government in I. R. Iran. Journal of Government Information, 30(5), 600-619.

Song, C. (2010, August 12-15). Validating IS Success Factors: An Empirical Study on Webbased State or Local E-government Systems. Paper presented at the Sixteenth Americas Conference on Information Systems (AMCIS), Lima, Peru.

Taylor, S., \& Todd, P. (1995a). Assessing IT Usage: The Role of Prior Experience. MIS Quarterly,, 19(4), 561-570.

Taylor, S., \& Todd, P. (1995b). Decomposition and Crossover Effects in the Theory of Planned Behavior: A Study of Consumer Adoption Intentions. International Journal of Research in Marketing, 12(2), 137-155.

Venkatesh, V., Brown, S. A., Maruping, L. M., \& Bala, H. (2008). Predicting Different Conceptualizations Of System Use: The Competing Roles Of Behavioral Intention, Facilitating Conditions, And Behavioral Expectation. MIS Quarterly, 32(3), 483-502.

Venkatesh, V., Morris, M. G., Davis, G. B., \& Davis, F. D. (2003). User Acceptance of Information Technology: Toward A Unified View. MIS Quarterly, 27(3), 425-447.

Verdegem, P., \& Verleye, G. (2009). User-Centered E-Government in Practice: A Comprehensive Model for Measuring user Satisfaction. Government Information Quarterly, 26(3), 487-497.

Wang, Y. S., \& Liao, Y. W. (2008). Assessing eGovernment Systems Success: A Validation of the DeLone and McLean Model of Information Systems Success. Government Information Quarterly, 25(4), 717-733.

Wangpipatwong, S., Chutimaskul, W., \& Papasratorn, B. (2005). Factors Influencing the Adoption of Thai e-Government Websites: Information Quality and System Quality Approach. International Journal of the Computer, the Internet and Management, 13(SP3), 14.11-14.17.

West, D. M. (2001). State and Federal E-Government in the United States. The Internet Connection, 7(9), 9-10. 
West, D. M. (2004). E-Government and the Transformation of Service Delivery and Citizen Attitudes. Public administration review, 64(1), 15-27.

West, D. M. (2008). Improving Technology Utilization in Electronic Government around the World. Brookings, Washington, DC., U.S.A.

Wixom, B. H., \& Todd, P. A. (2005). A Theoretical Integration of User Satisfaction and Technology Acceptance. Information Systems Research, 16(1), 85-102.

Yue, C. K. (2010). Impacts of Technology Implementation on Individual Behaviors:Three Essays. Hong Kong: The Hong Kong University of Science and Technology. 